\title{
A Simple Method for Estimating Dihydroxyacetone (or Glyceraldehyde) ${ }^{1}$
}

\author{
M. U. TSAO AND E. L. SCHWARTZ \\ From the Department of Pediatrics and Communicable Diseases, \\ University of Michigan Medical School, Ann Arbor, Michigan
}

Received October 30, 1961

INTRODUCTION

A procedure for the microdetermination of dihydroxyacetone (DHA) in biological fluids has been reported by us (1). Because of its relative time-consuming manipulations, a simpler procedure is sought in sacrifice of accuracy for brevity. This paper describes a new method which is based on the reaction between $\alpha$-hydroxycarbonyl compounds and pyridine nucleotides to form addition compounds (2). With this new method, it is quite simple to follow the appearance or disappearance rate of added DHA content in the blood of an animal or in the incubating tissue homogenate. The sample is diluted with water and deproteinized with $\mathrm{Ba}(\mathrm{OH})_{2}$ and $\mathrm{ZnSO}_{4}$. The supernatant is mixed with a solution of diphosphopyridine nucleotide (DPN) and tris(hydroxymethyl)aminomethane (Tris) solution of $\mathrm{pH} 10$ and heated at $56^{\circ}$. After clarification of the mixture, the absorbance at $340 \mathrm{~m} \mu$ is measured. The measurement is made against a reagent blank, but is compared with a baseline blank which represents the blood before the ingestion of DHA by the animal or the homogenate before the addition of DHA. It follows then that only the change in DHA is determined and no absolute DHA level can be obtained by this method. This is analogous to the measurement of gage pressure. Glucose interference which figures in procedures utilizing 2,4-dinitrophenylhydrazine, and had to be eliminated in our previous method, is completely avoided with this new method.

\section{REAGENTS}

Diphosphopyridine Nucleotide (DPN). A $0.03 M$ solution is prepared by dissolving $200 \mathrm{mg}$ of the nucleotide (Nutritional Biochemical Corp.)

\footnotetext{
${ }^{1}$ This work was supported by a grant from the National Institute of Arthritis and Metabolic Diseases of the Tnited States Public Health Service (A-5152)
} 
in several milliliters of water, adding approximately $1.5 \mathrm{ml}$ of $N / 10$ $\mathrm{NaOH}$ to bring the $\mathrm{pH}$ to 6 , and finally making up to $10 \mathrm{ml}$ with water.

Barium Hydroxide. A $0.3 \mathrm{~N}$ solution is prepared in $\mathrm{CO}_{2}$-free water.

Zinc Sulfate. A $5 \%$ solution of $\mathrm{ZnSO}_{4} \cdot 7 \mathrm{H}_{2} \mathrm{O}$ is prepared, titrated against the $\mathrm{Ba}(\mathrm{OH})_{2}$, and adjusted to equal normality of the latter.

Tris (hydroxymethyl)aminomethane (Tris $3 M$ ). In $100 \mathrm{ml}$ of water $36.3 \mathrm{gm}$ of Tris is dissolved and sufficient $1 \mathrm{~N} \mathrm{HCl}$ added to adjust the $\mathrm{pH}$ to 10 .

\section{PROCEDURE}

A $0.1-\mathrm{ml}$ sample is pipetted into $3.5 \mathrm{ml}$ of distilled water in a $5-\mathrm{ml}$ centrifuge tube. With mixing, $0.2 \mathrm{ml}$ of $\mathrm{Ba}(\mathrm{OH})_{2}$ followed by $0.2 \mathrm{ml}$ of $\mathrm{ZnSO}_{4}$ are added. Immediately, the mixture is centrifuged for $10 \mathrm{~min}$ at $375 \times g$. The samples, the baseline blanks, and standard DHA solutions are prepared in duplicate. A single reagent blank is prepared.

Three milliliters of the supernatant is pipetted into $0.2 \mathrm{ml}$ of DPN solution in $5-\mathrm{ml}$ centrifuge tubes. To these tubes is added $0.1 \mathrm{ml}$ of Tris buffer. The tubes are covered with tin foil and heated at $56^{\circ}$ for $1 \mathrm{hr}$. If a precipitate is formed, the solutions are centrifuged at $375 \times g$ for $5 \mathrm{~min}$. The supernatant is read at $340 \mathrm{~m} \mu$ in a spectrophotometer such as Beckman DU against the reagent blank.

Calculations. The difference between the absorbance reading of a sample and that of the baseline blank is used to calculate the change in DHA concentration, since both are read against the reagent blank:

$$
\text { Change in DHA conen. }=C_{\text {standard }} \times \frac{\left(E_{\text {sample }}-E_{\text {baseline blank }}\right)}{E_{\text {atandard }}}
$$

where $C$ is DHA concentration and $E$ is absorbance reading.

\section{EXPERIMENTAL}

\section{Conditions Used in the Procedure}

The $\mathrm{pH}$, the temperature, and the duration of heating determine the completeness of the reaction between DHA and DPN. The maintenance of $\mathrm{pH}$ precisely at 10 is not critical as long as the other two conditions would permit the completion of the reaction. At room temperature and the concentration range of DHA described in this paper, practically no DHA-DPN complex was detected regardless of the length of time allowed for the reaction. At $37^{\circ}$, the reaction still was not complete after $24 \mathrm{hr}$. At $56^{\circ}$, the reaction was presumed to have reached equilibrium after $1 \mathrm{hr}$ because no greater absorbance at $340 \mathrm{~m} \mu$ was observed after longer heating. 


\section{Linearity of Standard Curve}

Blood samples containing added dihydroxyacetone in $0.015,0.15,0.30$, and $0.50 \mathrm{mg} / \mathrm{ml}$ amounts were analyzed by the procedure described. Three such standard curves were obtained: the absorbance readings were all found to be proportional to the concentration of the triose. However, a significant difference between the slopes of these lincs was noted.

\section{Reproducibility of the Procedure}

To three samples of hemolyzate of washed human erythrocytes and two samples of the supernatant of rat liver homogenate was added a DHA solution $(6.0 \mathrm{mg} / \mathrm{ml})$ to obtain an increase of $0.3 \mathrm{mg} / \mathrm{ml}$ of DHA. The mixtures were each divided into eleven portions and analyzed according to the procedure described for the increment of DHA. For the erythrocyte samples the standard deviation was: $7.8,5.2$, and $9.8 \mu \mathrm{g} / \mathrm{ml}$. For the supernatant of rat liver homogenate the standard deviation was 7.3 and $10.1 \mu \mathrm{g} / \mathrm{ml}$.

\section{Recovery of Added Dihydroxyacetone}

Recovery of DHA was determined when calculated amounts were added to hemolyzate from saline washed and reconstituted human erythrocytes and crude homogenates of rat organs. Various amounts of DHA were added to the hemolyzate while $0.3 \mathrm{mg} / \mathrm{ml}$ of DHA was added to all of the homogenates. The homogenates were prepared by grinding $2.5 \mathrm{gm}$ of tissue with $4.0 \mathrm{ml}$ of a phosphate buffer in a Potter-Elvehjem homogenizer and straining through a cheese cloth. A $6 \mathrm{mg} / \mathrm{ml}$ DHA solution was used for all the additions of DHA to the hemolyzate and strained homogenates. The average of duplicate analyses that were made of the samples before and after the addition of DHA are shown in Table 1.

TABLE 1

Recovery of ADDED Dihydroxyacetone

\begin{tabular}{|c|c|c|c|c|}
\hline \multicolumn{5}{|l|}{ Erythrocytes } \\
\hline $\begin{array}{l}\text { Amt. of } \mathrm{DHA} \\
\text { added }(\mathrm{mg} / \mathrm{ml})\end{array}$ & 0.50 & 0.30 & 0.15 & 0.015 \\
\hline $\begin{array}{l}\text { Per cent } \\
\quad \text { recovered }\end{array}$ & $98,101,94$ & $98,97,102,96,91$ & $93,93,108$ & $86,100,91$ \\
\hline
\end{tabular}

Homogenates with $0.3 \mathrm{mg} / \mathrm{ml}$ DHA added

\begin{tabular}{lcccc}
$\begin{array}{l}\text { Organ } \\
\text { Per cent } \\
\text { recovered }\end{array}$ & Liver & Heart & Muscle & Kidney \\
\hline
\end{tabular}




\section{Interfering Substances}

With our previous method, glucose was a serious interfering material. With this procedure, a solution containing $2.0 \mathrm{mg} / \mathrm{ml}$ of glucose gave no increment in color over the blank. A $0.3 \mathrm{mg} / \mathrm{ml}$ glyceraldehyde solution was compared with a $0.15 \mathrm{mg} / \mathrm{ml} \mathrm{DHA}$ solution. The former gave the absorbance equivalent to $0.136 \mathrm{mg} / \mathrm{ml}$ of $\mathrm{DHA}$. Hence, this procedure can be used to measure glyceraldehyde. Obviously, glyceraldehyde is a serious interfering substance for DHA estimation, and vice versa. Acetone was examined at two concentrations: 0.8 and $4.75 \mathrm{mg} / \mathrm{ml}$. The former gave no interference while the latter gave an absorbance equivalent to $0.12 \mathrm{mg} / \mathrm{ml}$ of DHA. Pyruvic acid (lithium salt) at the concentration of $1.0 \mathrm{mg} / \mathrm{ml}$ gave the equivalent of $0.04 \mathrm{mg} / \mathrm{ml}$ of $\mathrm{DHA}$ in absorbance. These results support the original observation of Burton and Kaplan (2) that carbonyl compounds with a hydroxyl group on the adjacent carbon atom react with DPN to form addition compounds.

\section{SUMMARY}

A simple method for the measurement of changes in dihydroxyacetone in biological samples has been developed. It is based on the reaction between the triose and diphosphopyridine nucleotide in alkaline solution. Glucose does not interfere but carbonyl compounds do. The effective range of the procedure is from $2 \mu \mathrm{g}$ of dihydroxyacetone; and linearity between concentration and absorbance has been established up to $50 \mu \mathrm{g}$. The precision of the method has been measured.

\section{REFERENCES}

1. TSao, M. U., and Schwartz, E. L., Anal. Biochem. 2, 107 (1961).

2. Burton, R. M., and Kaplan, N. O., J. Biol. Chem. 206, 283 (1954). 